ex Instituto Archaeologico Universitatis de Rolando Eötvös nominatae

C

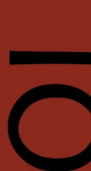

ப

$\varangle$

工

$\cup$

ه

$<$

in

ㄴ
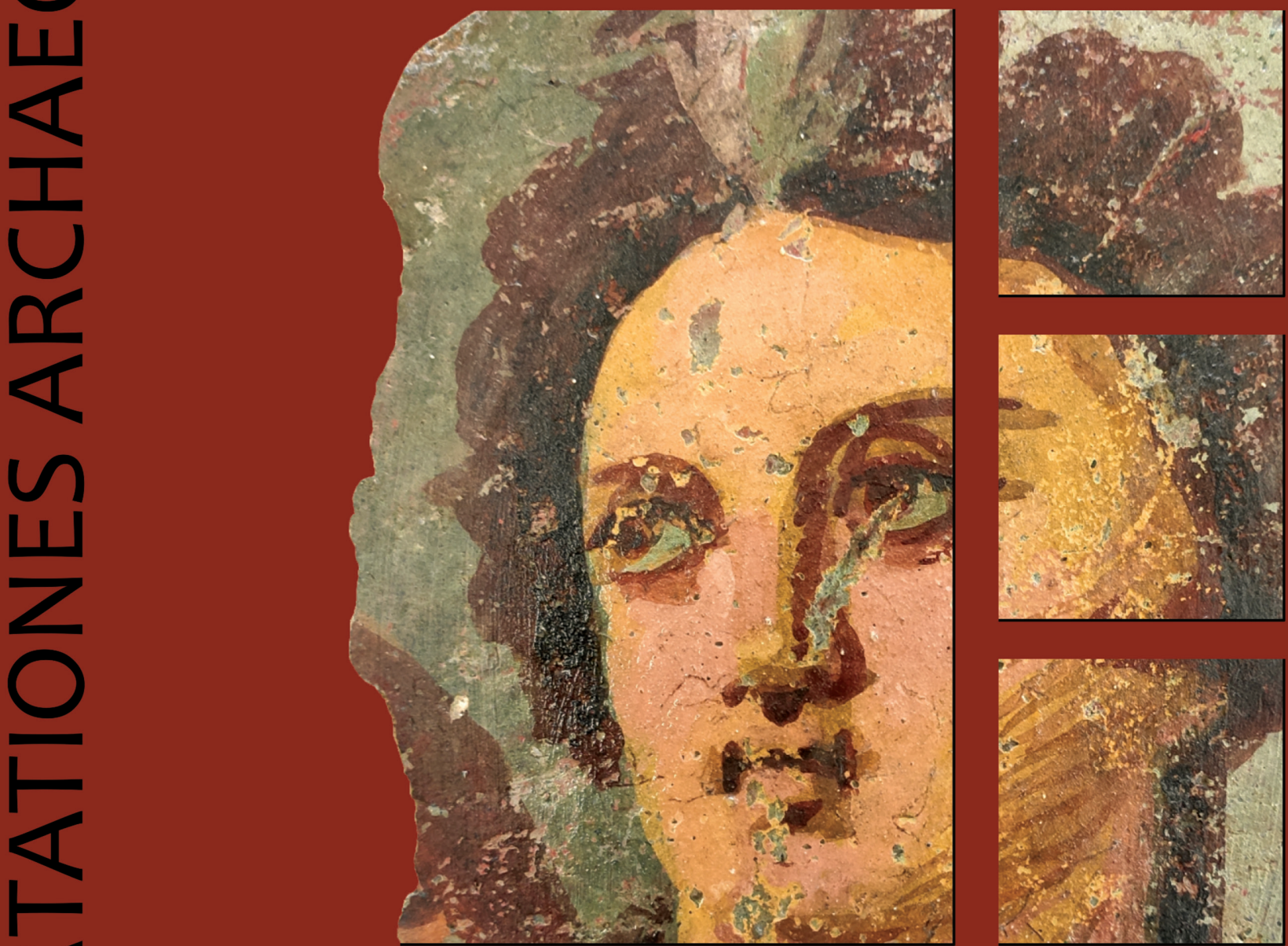

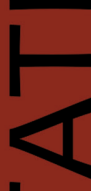

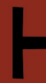

ח

Ш

un

n

0
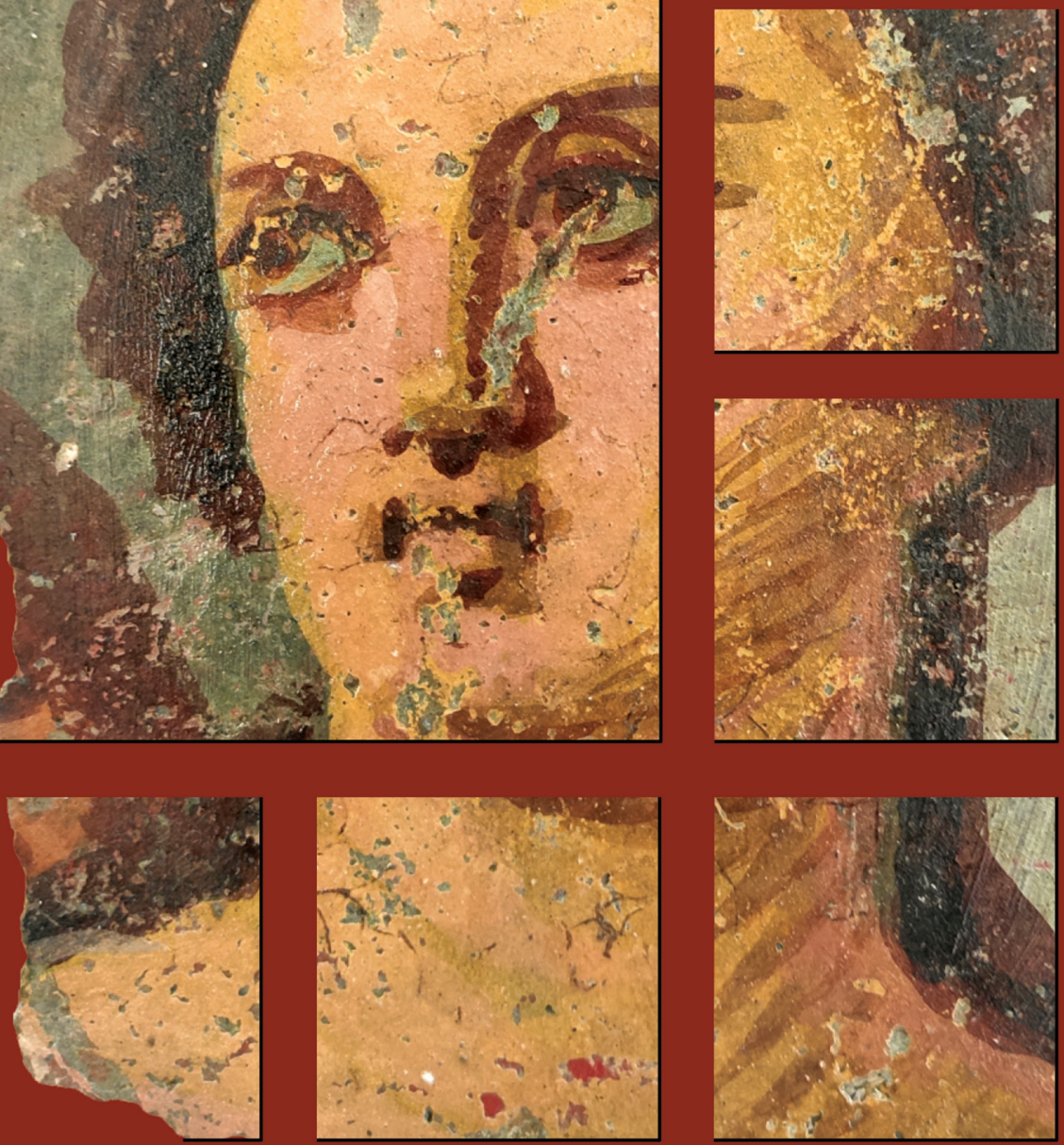

Serp 30 No. 8. 2020 


\section{Dissertationes Archaeologicae ex Instituto Archaeologico}

Universitatis de Rolando Eötvös nominatae Ser. 3. No. 8.

Budapest 2020 
Dissertationes Archaeologicae ex Instituto Archaeologico Universitatis de Rolando Eötvös nominatae Ser. 3. No. 8.

Editor-in-chief:

DÁvid Bartus

Editorial board:

LÁsZló BARTOSIEWICZ

LÁsZLÓ BORHY

ZOLTÁN CZAJLIK

IsTVÁN FELD

GÁBOR KALLA

PÁL RACZKY

MiKLÓS SZABÓ

Tivadar Vida

Technical editor:

Gábor VÁczi

Proofreading:

Szilvia BARTUS-SzÖLLŐsI

Zsófia KondÉ

Márton SZILÁGYI

Aviable online at http://ojs.elte.hu/dissarch

Contact: dissarch@btk.elte.hu

ISSN 2064-4574

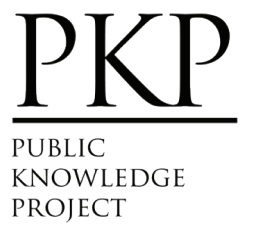

๑ ELTE Eötvös Loránd University, Institute of Archaeological Sciences

Layout and cover design: Gábor Váczi

Budapest 2020 


\section{CONTENTS}

\section{ARTICLES}

Maciej WAWRZCZAK - Zuzana KASENČÁKovÁ

Stará L'ubovña - Lesopark. Late Palaeolithic site and the problems associated with raw material mining

Attila PÉNTEK - Norbert FARAgó

Chipped stone assemblages from Schleswig-Holstein (North Germany) in the collection of the Institute of Archaeological Sciences - ELTE Eötvös Loránd University

Bence Soós 49

Middle Iron Age Cemetery from Alsónyék, Hungary

Tamás Szeniczey - Tamás Hajdu 107

Appendix - Results of the analysis of the Early Iron Age human remains unearthed at Alsónyék, Hungary

Lajos JuHÁsz - József Géza Kiss

Bound in bronze - a Roman bronze statuette of a barbarian prisoner

Csilla SÁRó

The fibula production of Brigetio: clay moulds

\section{Field Reports}

András Füzesi - Knut Rassmann - Eszter BÁnffy - Hajo Hoehler-Brockmann -

Gábor Kalla - Nóra Szabó - Márton SzIlágyi - Pál Raczky

Test excavation of the "pseudo-ditch" system of the Late Neolithic settlement complex at Öcsöd-Kováshalom on the Great Hungarian Plain

Gábor VÁczi - László RupNIK - Zoltán CZAJLIK - Gábor MEsterházy Bettina BitTner - Kristóf FÜlöP - Denisa M. LÖNHARdT - Nóra Szabó

The results of a non-destructive site exploration and a rescue excavation at the site of Pusztaszabolcs-Dohányos völgy északi part

Dávid BArtus - László Borhy - Szilvia JohÁczi - Emese SzÁmadó 181

Excavations in the legionary fortress of Brigetio in 2019 
Dávid BArtus - László Borhy - Emese SzÁmadó - Lajos Juhász - Bence Simon -

Ferenc Barna - Anita Benes - Szilvia Joháczi - Rita Olasz - Melinda Szabó

Excavations in Brigetio in 2020

\section{Thesis Abstracts}

Anett OszTÁs

The settlement history of Alsónyék-Bátaszék.

Complex analysis of its buildings in the context of the Lengyel culture

Csilla SzÁRAz

The region of the Zala and Mura Rivers (Zala County) in the Late Bronze Age.

Late Tumulus and Urnfield period

Ágnes KIRÁly

Human remains unearthed in settlement context from the Late Bronze Age -

Early Iron Age (Reinecke BD-HaB3) Northeastern Hungary

Gergely BóKA

Transformation of settlement history in the Körös Region in the period between the Late Bronze Age and the end of Iron Age

Gabriella G. DeLbó

Pottery production of the settlement complex of Brigetio

Adrienn Katalin BLAY

Die Beziehungen zwischen dem Karpatenbecken und dem Mediterraneum

von der II. Hälfte des 6. bis zum 8. Jahrhundert n. Chr. anhand Schmuckstücken

und Kleidungszubehör

Levente SAMU

293

Die mediterranen Kontakte des Karpatenbeckens in der Früh- und Mittel-

awarenzeit im Licht der Männerkleidung. Gürtelschnallen und Gürtelgarnituren

\section{REviEWS}

Gábor MESTERHÁZY

Czajlik, Z. - Črešnar, M. - Doneus, M. - Fera, M. - Hellmith Kramberger, A. Mele, M. (eds): Researching Archaelogical Landscapes Across Borders - Strategies,

Methods and Decisions for the 21th Century. Graz-Budapest, 2019. 


\title{
Bound in bronze - a Roman bronze statuette of a barbarian prisoner
}

\section{Lajos JuHÁsz}

Institute of Archaeological Sciences

ELTE Eötvös Loránd University

juhasz.lajos@btk.elte.hu
József Géza Kiss

Independent researcher Hungarian Numismatic Society

dr.kiss.jozsef.geza@gmail.com

\begin{abstract}
The small statuette of a bound barbarian from a Hungarian private collection is an interesting addition to the small group of these similar, although unusually harsh Roman representations of their foes. Although without a known findspot it further strengthens the previous suppositions that these were made and used for an unknown purpose at the limes, their greatest concentration being in Carnuntum.
\end{abstract}

While having the great pleasure of being invited to visit the considerable antiquities collection of a Hungarian private collector, a small bronze statuette immediately caught our attention. Upon the next visit we asked to see this object again for a more thorough analysis. During the inspection it became clear that it still contained some earth, which was then skilfully removed by the collector.

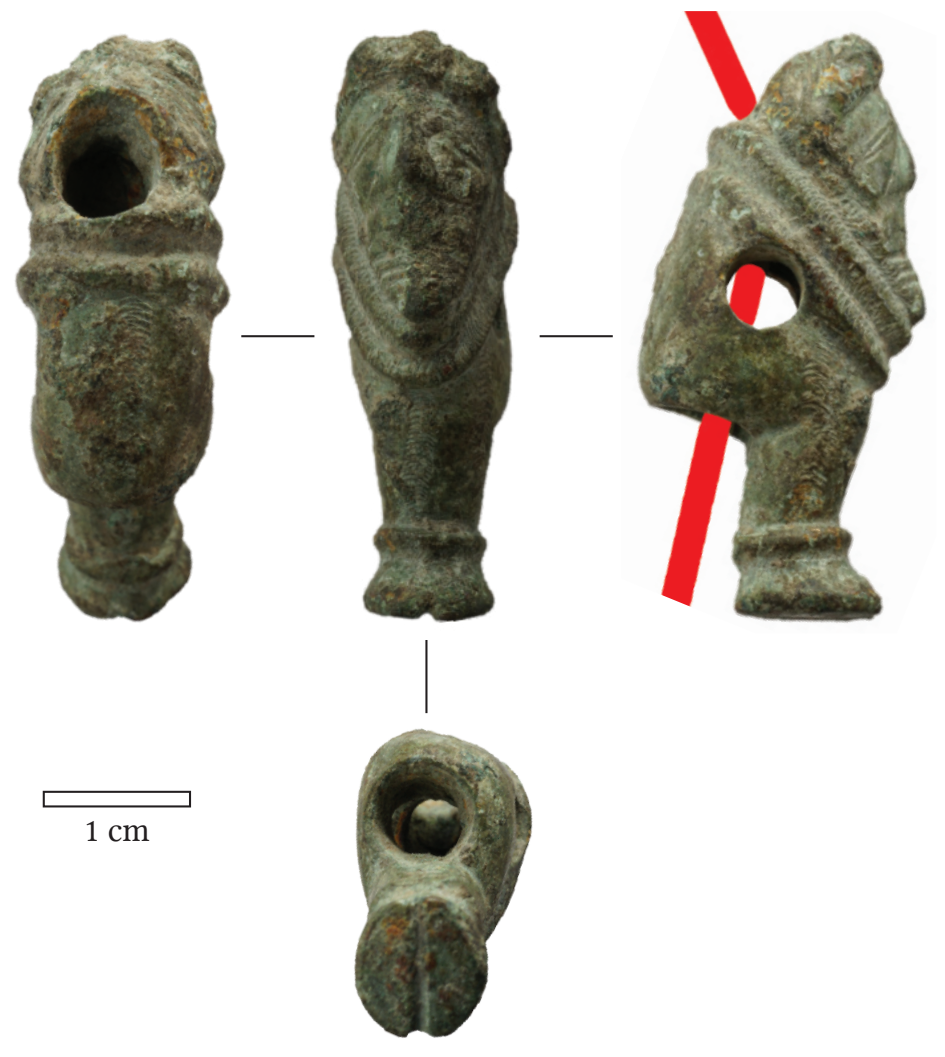

Fig. 1. Bound captive from a Hungarian private collection.
The bronze statuette measures 3.9 $\mathrm{cm}$ in height, $1.2 \mathrm{~cm}$ in width and $1.9 \mathrm{~cm}$ in depth, is evenly covered in dark green patina with small traces of red oxidisation (Fig. 1). It depicts a bound male prisoner in a seated position, the legs and the torso being at an appr. $90^{\circ}$ angle. The figure is bound by a rope, indicated by short incised lines, running from his neck, down before his knees and around his ankles. No hands are visible, but it has to be assumed that they were intended to be folded before the torso under the chin, otherwise this rectangular shape of the body could not be explained. This is also supported by the parallels in the archaeological material that will be discussed below. At his shoulders below the rope another bulge with the same short incisions 


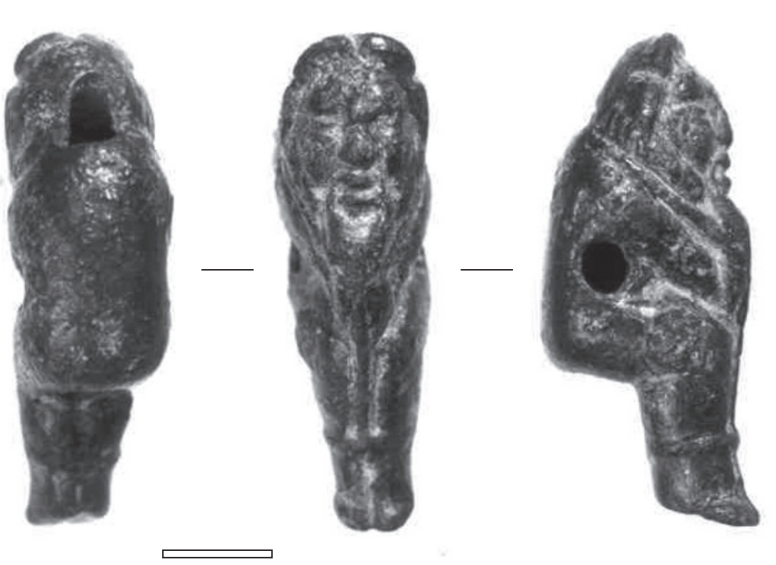

Fig. 2. Bound captive in the Kuny Domokos Museum - Tata (Photo: S. Petényi, by courtesy of K. R. Krierer).

is visible, indicating another hoop. The short incised lines are also running from the neck down towards the bulge on the ankle. More irregular strokes are visible on both sides between the neck and the ankles. The crouched posture and the narrowness of the figure are explained by the extreme tightness of the rope. The groove separating the feet also runs between the soles at the bottom of the statuette. The round feet, especially visible from the bottom, are the most unrealistic part of the object.

The disproportionately large, elongated head is depicted with offset wavy hair above the forehead, vertical lines indicate combing at the back of the head. The head is further characterised by a long triangular nose, narrow and unrealistically elongated almond shaped eyes running towards the non-existent ears. The mouth is depicted by a horizontal line above a pointy beard decorated with further incisions.

The statuette is pierced by 3 holes. The most obvious is a horizontal one measuring $4 \mathrm{~mm}$ going through the whole body at the stomach area, intersecting a small part of the lower rope around the neck. The second one is a $6 \mathrm{~mm}$ hole at the back of the head slightly displaced towards the left. ${ }^{1}$ The third one, also $6 \mathrm{~mm}$ wide, starts off at the bottom and goes through the whole body.

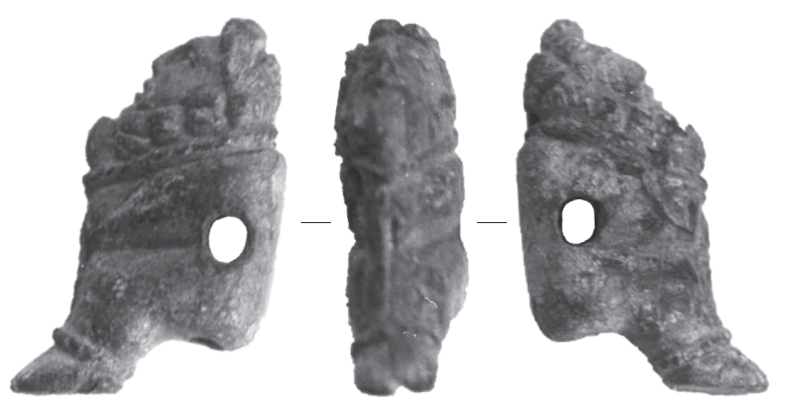

Fig. 3. Bound captive once supposedly in the Kuny Domokos Múzeum Tata (Photo: S. Petényi, by courtesy of K. R. Krierer).
Hole number 2 and 3 although connected but are at an appr. $130^{\circ}$ angle, therefore it is unlikely that a single pin went through both ends of the wholes, or it must have been of a flexible material e.g. a leather strap. The bottom and side holes overlap each other. This unusual and complicated way of fastening the statuette indicates a very specific function that is still unresolved. The round feet would have given a greater standing surface for the piece if placed down, but the holes suggest otherwise. ${ }^{2}$

Unfortunately, the findspot of the statuette is not known, nor can the collector remember when and where it was acquired, although it is unlikely that it came from outside of Hungary. A number of very close parallels of bound prisoner statuettes were previously discovered and published, although most of them also surfaced in private collections.

One is in the collection of the Kuny Domokos Museum at Tata measuring $4.1 \times 1.3 \mathrm{~cm}$ (Fig. 2). ${ }^{3}$

1 A similarly to the left displaced small cavity, although not a penetrating hole can be seen on the seated Germanic captive with hands bound behind his back. JuHÁsz 2014, 343.

2 More on the discussion of the function see below.

3 Krierer 2004, Kat. 287. 
The statuette has a similarly narrow body, elongated head with offset hair and ropes running from the neck to the ankles in front of the body. It also has $4 \mathrm{~mm}$ wide holes laterally at the stomach area, at the back of the head and at the bottom. The latter two are not round but are somewhat elongated at the beginning. Another difference is that the arms and legs are clearly distinguished by a grove running from the front rope to the lateral hole. The findspot is unknown, but Brigetio would be a likely place of origin, since a great deal of artefacts from there were brought to the museum in Tata. K. R.

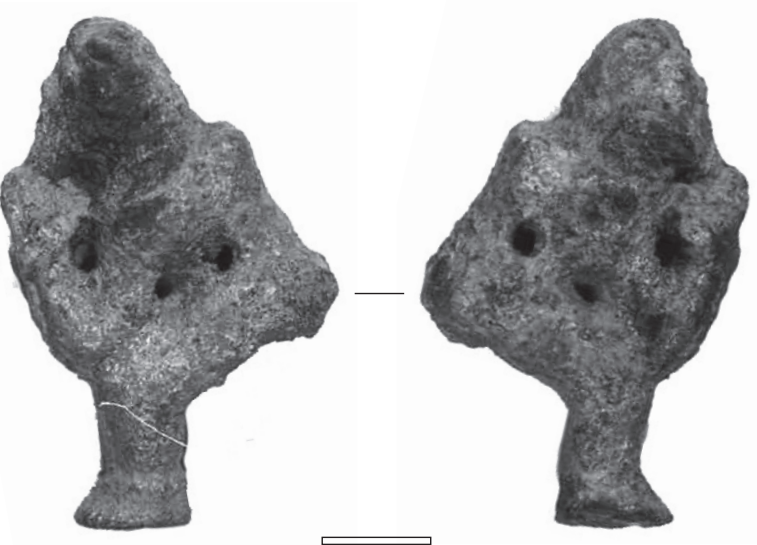

Fig. 4. Bound captive once supposedly in the Kuny Domokos Múzeum Tata (Photo: S. Petényi, by courtesy of K. R. Krierer).

Krierer in the initial publication of the statuette also listed two other similar bound captives from the same collection. I inquired about these upon my visit to the Kuny Domokos Museum, where I was only shown a single piece by S. Petényi, who originally sent the photos to Krierer, stating that there was never more than one. However, the photos Krierer was kind enough to send me, clearly show three different statuettes of bound captives. One is very similar to the previously described one, only differing in the more raised face, the more detailed hands as well as that the legs and feet are at an obtuse angle (Fig. 3). ${ }^{4}$ The third is appr. $5 \mathrm{~cm}$ long and more detailed with clearly visible hands and four lateral holes: two in the stomach area, one behind the hands and one below the beard (Fig. 4). ${ }^{5}$

The greatest concentration of these statues of bound captives is in Carnuntum, where 8 pieces were uncovered. Three of them have been known for decades, the rest were only recently published. Interestingly enough, one is made of bone and has no holes. ${ }^{6}$ Quite similar to the Hungarian piece is the one measuring $4 \mathrm{~cm}$ and has the same emplacement of holes. ${ }^{7}$ Another only slightly taller statuette $(4.2 \mathrm{~cm})$ has more bent legs and has its vertical hole somewhat lower in the stomach area. ${ }^{8}$ Both have more realistically executed faces and beards. The piece found

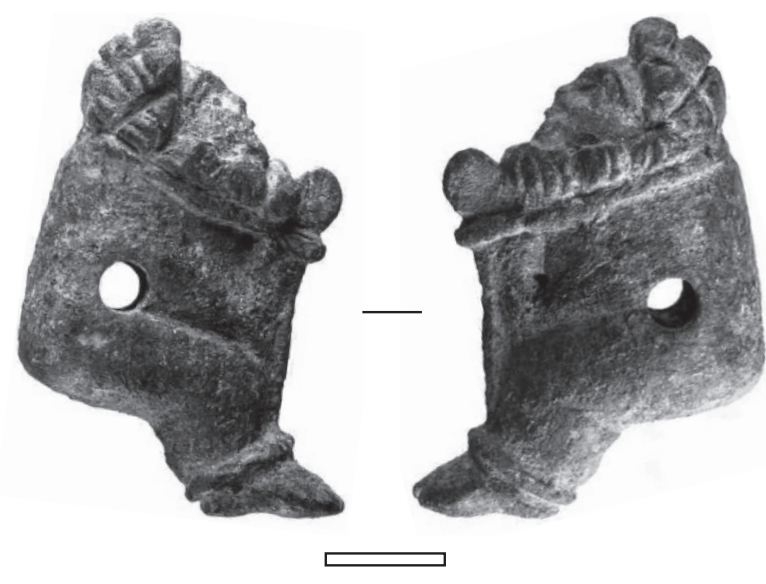

Fig. 5. Bound captive from Höflein (Photo: M. Kandler, by courtesy of K. R. Krierer). at Höflein near Carnuntum is the same height $(3.9 \mathrm{~cm})$ as the one from the Hungarian private collection (Fig. 5). ${ }^{9}$ The main difference is that the vertical rope and the hands are more pro-

KRIERER 2004, Kat. 290.

KRIERER 2004, Kat. 288.

BEUTLER ET AL. 2017, 435/1008.

BEUTLER ET AL. 2017, 434/1006.

BEUTLER ET AL. 2017, 435/1009.

Kandler 1976, 137-141; Melchart 1997, 72; Krierer 2004, Kat. 293. 
nounced, the hair and the beard is fuller. The size of the horizontal hole of $4 \mathrm{~mm}$ also corresponds to the piece published in this paper. The other two holes are also similarly placed as the one from the Hungarian private collection, although they are only $4 \mathrm{~mm}$ wide. Very similar is the statuette measuring $4 \mathrm{~cm}$ from the civil town of Vindobona (Fig. 6), although with a more detailed execution of the face. ${ }^{10}$ The feet resemble the piece kept in Tata but the figure has a more arched back. Another, more detailed piece with from Carnuntum is somewhat wider seen from the front (Fig. 7). ${ }^{11}$ Parts of the back are broken that could explain, why the lateral hole is missing. Peculiarly the bottom hole is lacking just like on the Vindobona statuette. ${ }^{12}$ A fur-
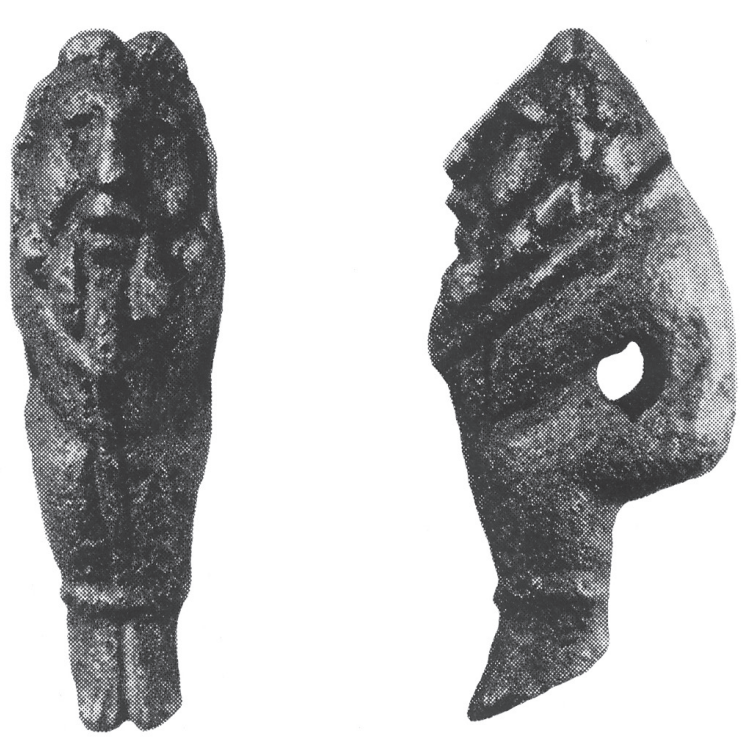

Fig. 6. Bound captive from Vindobona (Photo: FleisCHER 1967, Taf. 109/203a). ther similar example with a horizontal hole is known from Köln (Fig. 8) showing a more detailed face resembling the Carnuntinian piece. ${ }^{13}$ It has quite some depth compared to the previously listed statuettes with disproportionately long thighs compared to the lower legs. A further statuette $(3.7 \mathrm{~cm})$ from Carnuntum has a disproportionately large head compared to its very slim body that is not pierced by any holes. ${ }^{14}$

Quite different from the previous examples is again one from Carnuntum that is somewhat bigger $(4.7 \mathrm{~cm})$, but narrower and is also wearing a pointed hat. ${ }^{15}$ It has three holes, one vertical at the back and two horizontal; a larger one in the stomach area and a small-
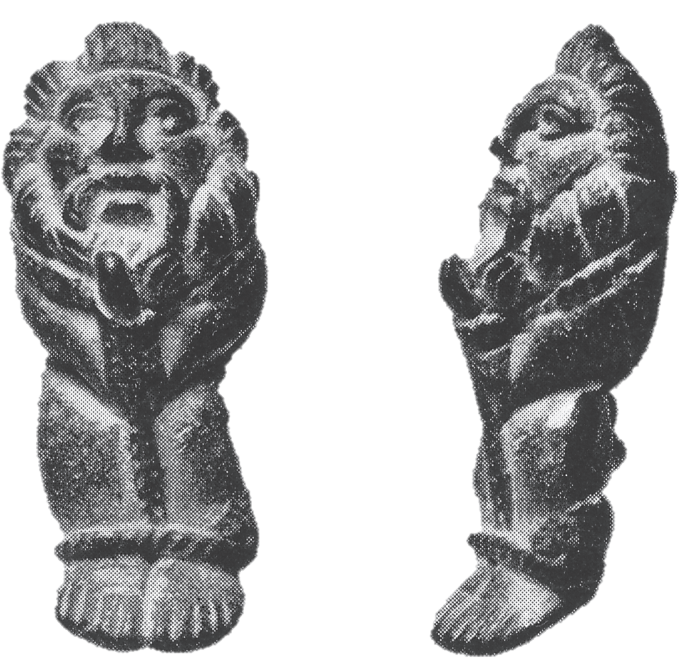

Fig. 7. Bound captive from Carnuntum (Photo: Fleischer 1967, Taf. 109/203). er one between the upper arms and the rope around the neck. Similar to this is the last Carnuntian piece of almost the same size $(4.8 \mathrm{~cm}) \mathrm{de}-$ picting a naked young beardless man with the arms not close at the body, but with some space between them, the rope standing freely between the neck, the hands and the feet (Fig. 9). ${ }^{16}$ The top hole is neatly placed behind the head on the back. Very similar, although only schematically represented bronze captive is known from Strasbourg with the arms and rope

10 Fleischer 1967, Nr. 203a; Krierer 2004, Kat. 279.

11 Fleischer 1967, Nr. 203; Krierer 2004, Kat. 277.

12 KANDLER 1976, 140.

13 BeHRENS 1916, 59.

14 Beutler et Al. 2017, 436/1010.

15 Beutler ET AL. 2017, 434-435/1007.

16 Behrens 1916, 59; Fleischer 1967, Nr. 202; Krierer 2004, Kat. 275. 


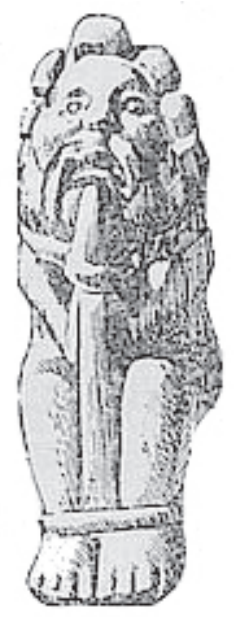

Fig. 8. Bound captive from Köln (Photo: BEHRENS 1916, 59/Abb. 25).

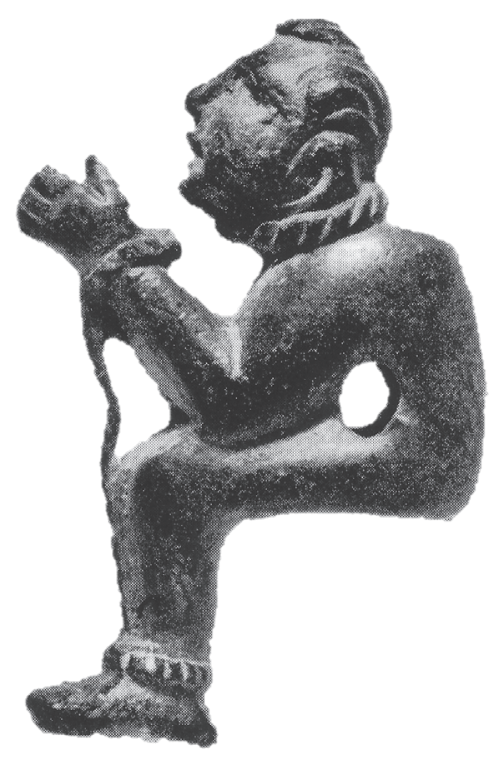

Fig. 9. Bound captive from Carnuntum (Photo: FLEISCHER 1967, Taf. 109/202). clearly visible through openwork technique (Fig. 10). ${ }^{17}$ Uniquely the upper hole was simply put on the top of the head.

The statuette from Mainz, often cited alongside these bound captives however is different in many ways. ${ }^{18}$ First of all, it is not bound by rope and the head on is laid on the left hand. It is seated on the ground with some small flat base and has a single horizontal hole at the hips. The figure seems to be in a more peaceful, easy pose that the tightly bound captives.

The numerous holes make the interpretation of the function of these finds difficult. Based on the double holes R. Fleischer supposed that they were part of a device or equipment. ${ }^{19}$ M. Kandler suggested that they were belt crossings of military horse bridles. ${ }^{20}$ However, no considerable wear marks are visible that would appear from a constant one-sided use. The seated posture of the figures also contradicts this, since a long and narrow form would have fitted better.

M. Kandler pointed out that these were all found by the limes, thus a military connection would be plausible. ${ }^{21}$ This is supported by the Höflein piece, which was found near the military camp overseeing the Carnuntum-Scarbantia road, although somewhat contradicted by the Vindobona piece found in the civil town. ${ }^{22}$ Representations of barbarians are well known from the middle Danubian border especially those with Suebian nodus for which it is the central area. ${ }^{23}$ Most of these with documented findspots came from the limes area, although not from military, but civilian environment. The inspiration was undoubtedly taken from the neighbouring Germanic people on the other side of the Danube. They also have three types of bound representations, although with their hands tied behind their backs: seated, standing and kneeling figures. ${ }^{24}$ Despite the ropes, their posture is not as tense as the other group.

17 BeHRENS 1916, 59.

18 Behrens 1916, 59.

19 Fleischer 1967, Nr. 202.

20 Melchart 1997, 72. This recently gained more acceptance. Beutler AT AL. 2017, 434-435/1006-1007.

21 KANDLER 1976, 140-141.

22 Cf. FleisCher 1967, 203a.

23 JuHÁsz 2015, 79-80.

24 JuHÁsz 2014, 342-343. 

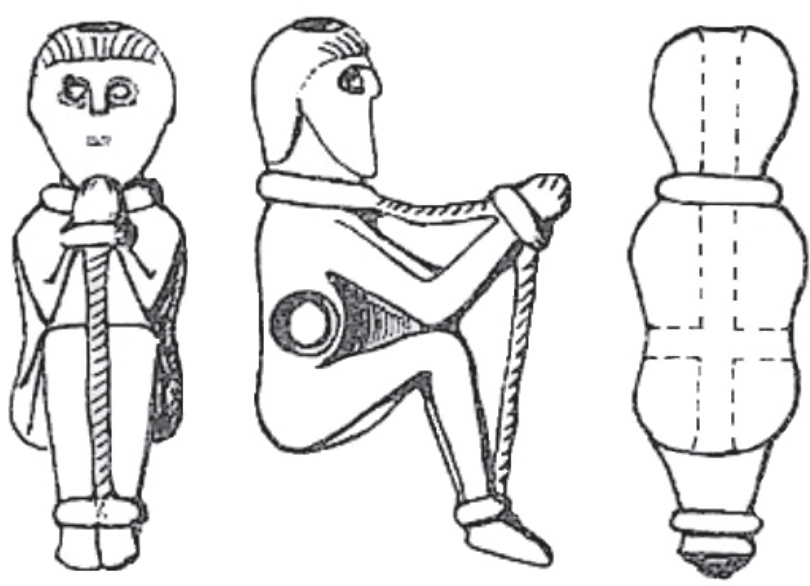

Fig. 10. Bound captive from Strasburg (Photo: BeHrens 1916, 59/Abb. 24).

their engaging army. Official Roman art treated woman more kindly, not tying them up, which was only reserved for the fighting men. ${ }^{26}$ The more direct representation in local bronze sculptures at the limes could possibly be inspired by of the anger towards the opposing inhabitants on the other side of the Danube that were a constant threat to the Pax Romana of everyday life on the borders.

\section{References}

BeHRens, G. 1916: Bronzefigürchen eines trauernden Gefangenen. Bericht der Römisch-Germanischen Kommission 6, 59-60.

Beutler, F. - Farka, Ch. - Gugl, Ch. - Humer, Fr. - Kremer, G. - Pollhammer, E. 2017: Der Adler Roms. Carnuntum und die Armee der Caesaren. Bad Vöslau.

FLEISCHER, R. 1967: Die römischen Bronzen aus Österreich. Mainz am Rhein.

JuhÁsz, L. 2014: Two new Roman bronzes with Suebian nodus from Brigetio. Dissertationes Archaeologicae 3/2, 333-349.

Juhász, L. 2015: Bronze head with Suebian nodus from Aquincum. Dissertationes Archaeologicae 3/3, 77-81. doi: 10.17204/dissarch.2015.77

KandleR, M. 1976: Neue Bronzestatuetten aus Carnuntum und Umgebung. Römisches Österrreich 4, 127-146.

KrIERER, K. R. 2004: Antike Germanenbilder. Archäologischer Forschungen 11. Wien.

Melchart, W. 1997: Antike Kostbarkeiten aus österreichischem Privatbesitz. Wien.

RIC II/1: CARradice, I. A. - Buttrey, T. V.: Roman Imperial Coinage II/1. London, 2007.

The depression is not centred, but leans somewhat to the left, just like the holes on the piece from Hungarian private collection. JuHÁsz 2014, 343.

26 An exception to the rule is the personification of Judea on the coins of Vespasian minted in 71, where the province is depicted with hands bound in front of her standing before a palm tree. The IVDAEA DEVICTA legend also stresses the severity of the image. RIC II/1 1119-1120. On a relief on the tropaeum in La Turbie the male captive is shown with hands chained at the back, while the woman chained in front of her body. 